\title{
DIFFERENCES IN RESULTS OBTAINED BY STUDENTS OF DIFFERENT FACULTIES
}

\author{
Miroslava Otavová1, Irena Sýkorová ${ }^{2 \bowtie}$ \\ ${ }^{1}$ Department of Mathematics, The Faculty of Informatics and Statistics, University of Economics, Prague, Czech Republic, Ekonomická 957, \\ Prague 4,140 00, +420 224095 233, otavova@vse.cz \\ ${ }^{2 \bowtie}$ Department of Mathematics, The Faculty of Informatics and Statistics, University of Economics, Prague, Czech Republic, Ekonomická 957, Prague \\ 4,140 00,+420 224094 235, sykorova@vse.cz
}

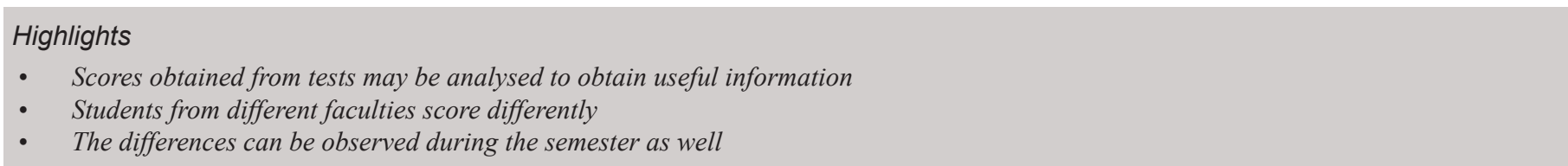

\begin{abstract}
The paper presents and discusses the results of statistical analysis of differences among scores obtained by students of different faculties of the University of Economics in Prague. The analysed dataset contains the scores for 2256 students that took basic mathematics course during the academic year 2013/2014.

A two way analysis of variance was performed with semester and faculty as main factors. The interaction between these two factors was also considered. Students have to take two tests. At first, the sum of the scores obtained from both tests is analysed and then, the two tests are analysed separately. It turns out that the significance of factors is the same in the three analyses. The assumptions of linear models are verified. Due to problem of heteroscedasticity, weighted least squares are used and the possibility of using Box-Cox transformation is also discussed, as the errors are not normally distributed. Finally, the differences between the faculties are described.
\end{abstract} Keywords

Analysis of variance, weighted least squares, linear regression, test in mathematics

Otavová M., Sýkorová I. (2016) "Differences in Results Obtained by Students of Different Faculties", Journal on Efficiency and Responsibility in Education and Science, Vol. 9, No. 1, pp. 1-6, online ISSN 1803-1617, printed ISSN 2336-2375, doi: 10.7160/ eriesj.2016.090101.

\section{Introduction}

Each student of the University of Economics in Prague has to take a mathematics course as the basic concepts of linear algebra and mathematical analysis are needed in other courses throughout the rest of student's studies. The Department of Mathematics of the Faculty of Informatics and Statistics offers the basic mathematics course in both, winter and summer semester and this course is compulsory for most of the study programmes. The syllabus of this course is identical to the textbook written by Klůfa (2013b). Beside this course, a similar course is offered in English for foreign exchange students. The latter course follows the textbook written by Klůfa and Kaspříková (2013).

Throughout the course, students have to take a mid-term test which is worth 20 points, a final test which is worth 40 points and an oral examination worth 40 points. The final grade is calculated as the sum of the scores from the three abovementioned parts and in order to pass, student has to obtain at least 60 points. The scores of the enrolled students provide a lot of information to the staff of the department and may be further analysed in order to improve teaching and evaluation methods. Different statistical methods can be used for this analysis. Hypothesis testing can be used in analysing the dependence of student's performance on his demographic and behavioural traits (Kasprríková, 2012), while probability is used for analysing student's performance in (Klůfa, 2012) and (Klůfa, 2013a). The analysis of dependence of student's performance on his abilities by using latent variables framework can be found in (Kaspř́ková, 2013), while correlation between the test scores and areas covered in the test is discussed in (Kaspř́ková, 2011). Otavová and Sýkorová (2014) analyse association between test scores in the mid-term and final test by using contingency table.
Several papers deal with factors which influence students' scores and performance. Pacáková (2013) discusses how students' test scores and students' motivation is influenced by allowing students to pass the course by obtaining enough points from tests during the semester. Sengodan and Iksan (2012) discuss types of intrinsic motivation in learning mathematics and differences in this motivation between genders. Boháčková and Brožová (2012) analyse which factors influence students' scores, differences among the students of different study programmes at one particular faculty and whether students obtain better scores when retaking the exam. Moreover, they discuss differences between performance of full-time and part-time students. Hassanbeigi et al (2011) study the relationship between several study skills (time management, concentration, test anxiety, etc.) and academic performance of students. Clotfelter et al (2007) discuss how teacher qualities influence students' results.

The purpose of this paper is to analyse the differences among the scores of students from different faculties of the University of Economics in different semesters. The drawback of the course is that the same course is followed by students of different study programmes at different faculties and it might be of interest whether there are differences in performance among students from different faculties. Hence, the aim is to discuss whether it is appropriate to have one common course for students of different faculties and whether the faculty of a student might be a factor that influences his performance. This paper is an extension of our previous paper (Otavová and Sýkorová, 2015).

Analysis of variance will be applied to the available dataset and statistical software R will be used for this analysis. At first, the sum scores from both tests will be analysed and then scores 
from both tests will be analysed separately, to verify whether the overall difference hold throughout the semester.

\section{Materials and Methods}

\section{Data description}

The dataset contains information about 2256 students who took the course of Mathematics for Economists (in Czech language) in the academic year 2013/2014. The dataset contains the score obtained in the mid-term test, the score obtained in the final test, the sum of these two scores, the faculty to which the student belongs (Faculty of Finance and Accounting - F1, Faculty of International Relations - F2, Faculty of Business Administration - F3, Faculty of Informatics and Statistics - F4 and Faculty of Economics - F5) and the semester in which the course was taken. The score from each test is considered as a continuous dependent variable and the other two variables, semester and faculty are considered as categorical factors. Table 1 shows the contingency table with number of observations, i.e. students, in each combination of categories.

\begin{tabular}{|l|l|c|c|c|c|c|c|}
\hline \multicolumn{2}{|c|}{} & \multicolumn{5}{|c|}{ Faculty } & \multirow{2}{*}{ Total } \\
\cline { 3 - 8 } \multicolumn{2}{|c|}{} & F1 & F2 & F3 & F4 & F5 & \\
\hline \multirow{2}{*}{ Semester } & Winter & 244 & 310 & 227 & 534 & 3 & 1318 \\
\cline { 2 - 8 } & Summer & 284 & 382 & 179 & 89 & 4 & 938 \\
\hline Total & & 528 & 692 & 406 & 623 & 7 & 2256 \\
\hline
\end{tabular}

Table 1: Contingency table of number of students in each treatment

We have to note that the course is not compulsory for students of Faculty of Economics (F5), as they have another course in mathematics. This fact is reflected in number of students enrolled from this faculty. Students from this faculty are either those who need an additional explanation as they are not confident in mathematics, or those who want to earn credits easily.

\section{Statistical methods}

The score from a test is a continuous response variable, while the independent variables are categorical factors. For this reason a two-way analysis of variance (ANOVA) is an appropriate method to analyse the differences among the groups, or treatments. The first factor, faculty, has 5 levels (F1, F2, F3, F4, F5), while the second factor, semester, has 2 levels (winter and summer). Hence, 10 treatments, or groups, are considered. Both of the factors are fixed factors, or fixed effects, as they are not a random sample from a greater population. For further information about difference between ANOVA with fixed effects, random effects and mixed effects see (Kutner et al., 2005) or (Sahai and Ageel, 2000).

As can be seen from Table 1, the number of observations in each treatment is not the same. Therefore, a linear regression approach has to be used instead of the usual ANOVA approach based on between and within group variability. At first, the model with interaction is considered, which allows the effect of faculty to be different in each semester. The considered model is in the following form:

$$
\begin{aligned}
Y_{i j k}= & \lambda+\alpha_{1} X_{i j k 1}+\alpha_{2} X_{i j k 2}+\alpha_{3} X_{i j k 3}+\alpha_{4} X_{i j k 4}+\beta_{1} X_{i j k 5}+ \\
& +\gamma_{1} X_{i j k 1} X_{i j k 5}+\gamma_{2} X_{i j k 2} X_{i j k 5}+\gamma_{3} X_{i j k 3} X_{i j k 5}+\gamma_{4} X_{i j k 4} X_{i j k 5}+\varepsilon_{i j k}, \\
& i=1,2,3,4,5 ; j=1,2 ; k=1, \ldots, n_{i j},
\end{aligned}
$$

where:

$Y_{i j k}$ is the number of points obtained by the $k$-th student from $i$-th faculty in $j$-th semester,

$X_{i j k 1}$ takes value of 1 if student is from the Faculty of Finance and Accounting, 0 otherwise,

$X_{i j k 2}$ takes value of 1 if student is from the Faculty of International Relations, 0 otherwise,

$X_{i j k 3}$ takes value of 1 if student is from the Faculty of Business Administration, 0 otherwise,

$X_{i j k 4}$ takes value of 1 if student is from the Faculty of Informatics and Statistics, 0 otherwise,

$X_{i j k 5}$ takes value of 1 if student took the course in winter semester, 0 if in the summer semester,

coefficients $\alpha_{1}, \alpha_{2}, \alpha_{3}, \alpha_{4}$ correspond to the effect of faculty,

coefficient $\beta_{1}$ corresponds to the effect of semester,

coefficients $\gamma_{1}, \gamma_{2}, \gamma_{3}, \gamma_{4}$ correspond to the interaction effect between semester and faculty,

$\lambda$ is an intercept,

$\varepsilon_{i j k}$ is the unexplained random error term,

and $n_{i j}$ is the number of observations in treatment defined by $i$-th faculty and $j$-th semester.

In order to test the significance of interaction terms, a reduced model has to be built:

$$
\begin{aligned}
Y_{i j k} & =\lambda+\alpha_{1} X_{i j k 1}+\alpha_{2} X_{i j k 2}+\alpha_{3} X_{i j k 3}+\alpha_{4} X_{i j k 4}+\beta_{1} X_{i j k 5}+\varepsilon_{i j k}, \\
i & =1,2,3,4,5 ; j=1,2 ; k=1, \ldots, n_{i j} .
\end{aligned}
$$

Afterwards a partial F-test is performed:

$$
\begin{gathered}
\mathrm{H}_{0}: \gamma_{1}=\gamma_{2}=\gamma_{3}=\gamma_{4}=0, \\
\mathrm{H}_{a}: \text { not all } \gamma_{i} \text { are equal to } 0, \\
F^{*}=\frac{\frac{S S E(2)-S S E(1)}{d f_{2}-d f_{1}}}{\frac{S S E(1)}{d f_{1}}},
\end{gathered}
$$

where:

SSE is the sum of squared errors from the model (1) or model (2), calculated by the following formula:

$$
S S E=\sum_{i=1}^{5} \sum_{j=1}^{2} \sum_{k=1}^{n_{i j}}\left(Y_{i j k}-\hat{Y}_{i j}\right)^{2},
$$

$d f$ is the number of degrees of freedom in the corresponding model calculated as the sample size (2256 students) minus the number of parameters in the model,

\section{$\hat{Y}_{i j .}$ in (5) is the fitted value estimated by the model.}

$F^{*}$ statistics defined in (4) follows Fisher-Snedecor distribution with corresponding degrees of freedom: $F^{*} \sim F\left(d f_{2}-d f_{1} ; d f_{1}\right)$. In case of one fails to reject the null hypothesis, the partial F-tests for significance of main effects of factors faculty and semester can be performed. Model (2) becomes the full model and the reduced models are built in the same way as in case of testing for the significance of interaction term, i.e. by omitting the terms and coefficients corresponding to the main effect tested. In this case type II sum of squares will be presented in the ANOVA table. On the other hand, if the interaction term is significant, i.e. the null hypothesis in (3) is rejected, the main effects should remain in 
the model even though they might be insignificant. In this case type III sum of squares should be used. For further information about the different types of sum of squares, i.e. different ways of specifying full and reduced models, see (Kutner et al., 2005). If all the coefficients in the model (1), turn out to be insignificant then there is no significant difference among the results of students from different faculties and in different semesters.

The regression model has to fulfil several assumptions so that the statistical inference is valid. The errors should be independent from each other, the variance should be the same in each treatment, the errors should come from the normal distribution and the mean of the errors should be zero. Apart from these assumptions, the dataset should not contain any outliers or influential observations. For further details see (Kutner et al., 2005).

\section{Results}

In this part, the results of three separate analyses are presented. At first, the results of analysis of variance and descriptive statistics for the sum of scores from both tests are presented. Subsequently, results of analysis of variance and descriptive statistics for mid-term test are presented and finally, the results and descriptive statistics for final test score are presented.

\section{Sum of Scores from Both Tests}

Table 2 shows the descriptive statistics for each of the treatments. One can see that the means are different in each group. The apparent problem is that the distribution of the scores in most of the treatments is negatively skewed as the median is higher than the mean of a treatment. This was also discussed in (Otavová and Sýkorová, 2014). This problem usually yields to skewed errors in the regression model, which means that the errors in the model will not be normally distributed. This may then cause the statistical inference to be invalid.

\begin{tabular}{|l|c|c|c|c|c|c|c|}
\hline \multirow{2}{*}{ Faculty } & Semester & Mean & Median & Min & Max & $\begin{array}{c}\text { Standard } \\
\text { deviation }\end{array}$ & $\begin{array}{c}\text { Num- } \\
\text { ber of } \\
\text { obs. }\end{array}$ \\
\hline \multirow{2}{*}{ F1 } & Winter & 42.39 & 44.00 & 8.00 & 60.00 & 11.47 & 244 \\
\cline { 2 - 8 } & Summer & 40.25 & 42.00 & 2.00 & 60.00 & 12.24 & 284 \\
\hline \multirow{2}{*}{ F2 } & Winter & 36.95 & 39.00 & 0.00 & 60.00 & 13.34 & 310 \\
\cline { 2 - 8 } & Summer & 40.02 & 41.75 & 8.00 & 60.00 & 11.98 & 382 \\
\hline \multirow{2}{*}{ F3 } & Winter & 38.92 & 40.00 & 0.00 & 60.00 & 12.52 & 227 \\
\cline { 2 - 8 } & Summer & 38.21 & 38.00 & 4.00 & 60.00 & 12.29 & 179 \\
\hline \multirow{2}{*}{ F4 } & Winter & 33.16 & 34.50 & 0.00 & 60.00 & 13.72 & 534 \\
\cline { 2 - 8 } & Summer & 32.15 & 32.00 & 4.00 & 55.00 & 11.53 & 89 \\
\hline \multirow{2}{*}{ F5 } & Winter & 23.33 & 25.00 & 8.00 & 37.00 & 14.57 & 3 \\
\cline { 2 - 8 } & Summer & 45.00 & 45.50 & 34.00 & 55.00 & 9.35 & 4 \\
\hline
\end{tabular}

Table 2: Descriptive statistics for each treatment

A more severe problem is the presence of heteroscedasticity, i.e. the variances are not equal for each treatment. Table 3 presents the results of Brown-Forsythe test for homogeneity of variances and it can be seen that the null hypothesis of homoscedasticity is rejected at $5 \%$ level of significance. This violation of the assumption of homoscedasticity can be solved by using weighted least squares, where the weight of an observation is set up to be the inverse of the variance of the treatment to which the observation belongs:

$$
w_{i j k}=\frac{1}{s_{i j}^{2}} .
$$

\begin{tabular}{|l|r|r|r|}
\hline & \multicolumn{1}{|c|}{ Df } & F-value & P-value \\
\hline Treatments & 9 & 2.5008 & 0.008 \\
\hline & 2246 & & \\
\hline
\end{tabular}

Table 3: Brown-Forsythe test for the homogeneity of variances

The boxplots on Figure 1 summarize Table 2 and Table 3 in a graphical way. In addition to the presence of heteroscedasticity and non-normality of the response variable score, some outliers are detected. Since the sample size is large and only a few students were turned out to be outliers, there is no need to remove them from the sample.

Table 4 presents the ANOVA table after fitting the linear regression model by using weighted least squares. It can be seen that the interaction between the two factors is significant at $5 \%$ level of significance, which proves that the differences in the average scores for students of different faculties are not the same in each semester. As the interaction is significant there is no need to look at the main effects of semester and faculty and both of them have to be retained in the model. Type III tests are showed in the table as the interaction effect is significant.

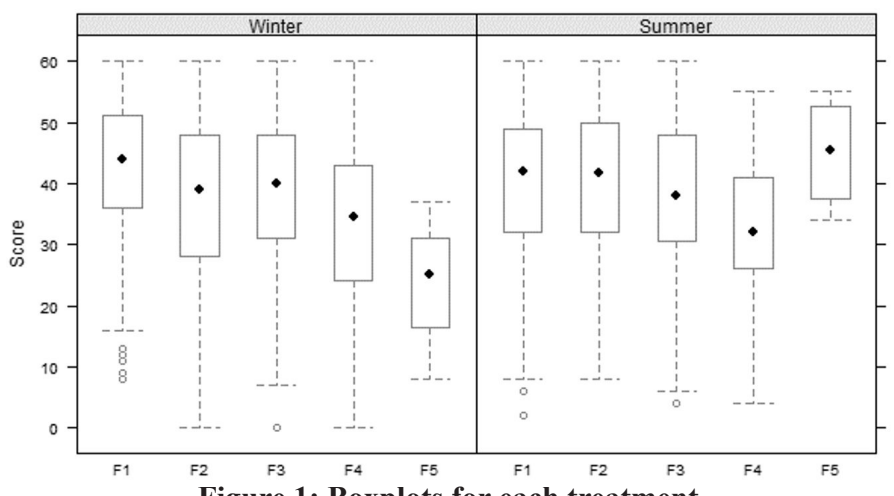

Figure 1: Boxplots for each treatment

\begin{tabular}{|l|r|r|r|r|r|}
\hline $\begin{array}{l}\text { Source of } \\
\text { variation }\end{array}$ & Df & $\begin{array}{c}\text { Sum of } \\
\text { squares }\end{array}$ & $\begin{array}{c}\text { Mean } \\
\text { square }\end{array}$ & F-value & P-value \\
\hline Intercept & 1 & 4837.6 & 4837.6 & 3203.557 & 0.000 \\
\hline Faculty & 4 & 61.3 & 15.3 & 10.157 & 0.000 \\
\hline Semester & 1 & 6.8 & 6.8 & 4.483 & 0.034 \\
\hline Faculty*Semester & 4 & 32.2 & 8.1 & 5.331 & 0.000 \\
\hline Errors & 2246 & 3391.7 & 1.5 & & \\
\hline
\end{tabular}

Table 4: ANOVA table (Type III sum of squares)

Concerning, the Gauss-Markov assumptions of linear models, the normality of errors assumption is violated, which is caused by the fact that the original response variable, i.e. sum of scores from both tests, is negatively skewed. A Box-Cox transformation could be applied to the response variable score which would made the distribution of the response variable score and the errors of the model more normal.

However, the violation of the assumption of normality of errors in the model with non-transformed response variable does not cause the statistical inference (F-tests) to give invalid conclusions and the results would be similar to those presented in Table 4. This is caused by the fact that the sample size is large enough. Moreover, the scores of students after the transformation loose a meaningful interpretation. For these reasons the results of analysis on non-transformed variable are presented in this paper. For further information about the Box-Cox transformation see (Kutner et al., 2005). 


\section{Mid-term Test}

In this part, the results for mid-term test are presented. From the descriptive statistics in Table 5, it can be noticed that the distribution of scores in most treatments is negatively skewed. Table 6 presents Brown-Forsythe test for homogeneity of variance and at $5 \%$ level of significance it can be concluded that heteroscedasticity is present, i.e. the variances are not equal in each treatment. Therefore, weighted least squares have to be used. Figure 2 again summarizes the findings in Table 5 and Table 6 in graphical way. Table 7 presents the results of analysis of variance where type III tests are used. As the interaction is highly significant, the main effects are kept in the model and each semester, there are differences among faculties each semester. The results of this analysis suggest that students of different faculties score differently even in the middle of the semester and should be approached in different way from the beginning of the course.

\begin{tabular}{|l|c|c|c|c|c|c|c|}
\hline Faculty & Semester & Mean & Median & Min & Max & $\begin{array}{c}\text { Standard } \\
\text { deviation }\end{array}$ & $\begin{array}{c}\text { Num- } \\
\text { ber of } \\
\text { obs. }\end{array}$ \\
\hline \multirow{2}{*}{ F1 } & Winter & 14.52 & 16.00 & 0.00 & 20.00 & 4.49 & 244 \\
\cline { 2 - 8 } & Summer & 13.78 & 15.00 & 0.00 & 20.00 & 4.94 & 284 \\
\hline \multirow{2}{*}{ F2 } & Winter & 12.26 & 13.00 & 0.00 & 20.00 & 5.33 & 310 \\
\cline { 2 - 8 } & Summer & 13.85 & 14.00 & 0.00 & 20.00 & 4.53 & 382 \\
\hline \multirow{2}{*}{ F3 } & Winter & 13.17 & 14.00 & 0.00 & 20.00 & 4.79 & 227 \\
\cline { 2 - 8 } & Summer & 12.49 & 13.00 & 0.00 & 20.00 & 5.20 & 179 \\
\hline \multirow{2}{*}{ F4 } & Winter & 11.32 & 12.00 & 0.00 & 20.00 & 5.11 & 534 \\
\cline { 2 - 8 } & Summer & 11.17 & 12.00 & 1.00 & 20.00 & 4.54 & 89 \\
\hline \multirow{2}{*}{ F5 } & Winter & 8.67 & 8.00 & 3.00 & 15.00 & 6.03 & 3 \\
\cline { 2 - 7 } & Summer & 15.50 & 16.00 & 12.00 & 18.00 & 2.65 & 4 \\
\hline
\end{tabular}

Table 5: Descriptive statistics for each treatment

\begin{tabular}{|l|r|c|c|}
\hline & \multicolumn{1}{|c|}{ Df } & F-value & P-value \\
\hline Treatments & 9 & 2.1252 & 0.025 \\
\hline & 2246 & & \\
\hline
\end{tabular}

Table 6: Brown-Forsythe test for the homogeneity of variances

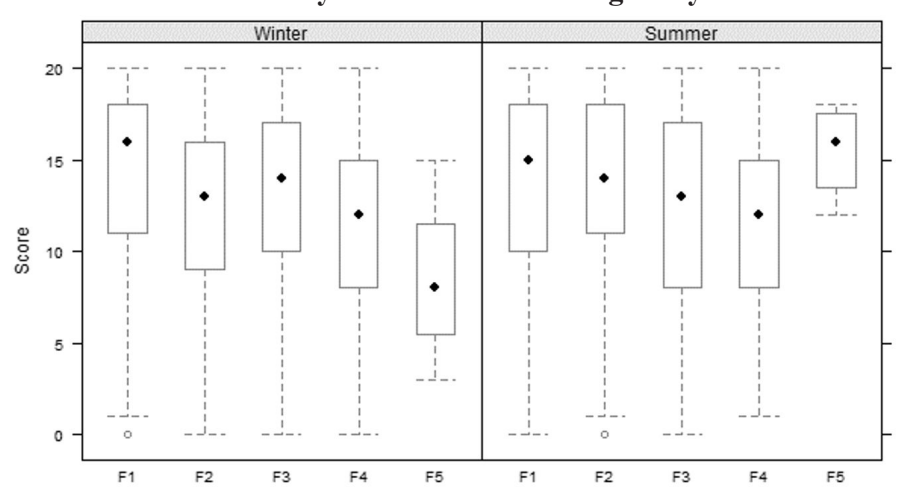

Figure 2: Boxplots for each treatment

\begin{tabular}{|l|r|r|r|r|r|}
\hline $\begin{array}{l}\text { Source of } \\
\text { variation }\end{array}$ & Df & $\begin{array}{c}\text { Sum of } \\
\text { squares }\end{array}$ & $\begin{array}{c}\text { Mean } \\
\text { square }\end{array}$ & F-value & P-value \\
\hline Intercept & 1 & 3207.5 & 3207.5 & 2197.522 & 0.000 \\
\hline Faculty & 4 & 52.0 & 13.0 & 8.908 & 0.000 \\
\hline Semester & 1 & 4.7 & 4.7 & 3.242 & 0.072 \\
\hline Faculty*Semester & 4 & 38.4 & 9.6 & 6.574 & 0.000 \\
\hline Errors & 2246 & 3278.2 & 1.5 & & \\
\hline
\end{tabular}

Table 7: ANOVA table (Type III sum of squares)

\section{Final Test}

In the last analysis, the score obtained from the final test was analysed. From the descriptive statistics in Table 8 one can notice that the distribution is negatively skewed like for the sum of scores and the score obtained in mid-term test. Table 9 presents the results of Brown-Forsythe test. One can see that at $5 \%$ level of significance we reject the null hypothesis of homoscedasticity. Therefore, the variance is different in each treatment and weighted least squares have to be used. Figure 3 summarises the descriptive statistics in a graphical way and Table 10 presents ANOVA table. Again, type III tests were used as the interaction, between semester and faculty turned out to be significant. Hence, the differences among faculties are different in each semester and the differences hold even during the exam period.

\begin{tabular}{|l|c|c|c|c|c|c|c|}
\hline Faculty & Semester & Mean & Median & Min & Max & $\begin{array}{c}\text { Standard } \\
\text { deviation }\end{array}$ & $\begin{array}{c}\text { Num- } \\
\text { ber of } \\
\text { obs. }\end{array}$ \\
\hline \multirow{2}{*}{ F1 } & Winter & 27.87 & 29.00 & 0.00 & 40.00 & 8.66 & 244 \\
\cline { 2 - 8 } & Summer & 26.47 & 27.50 & 0.00 & 40.00 & 9.29 & 284 \\
\hline \multirow{2}{*}{ F2 } & Winter & 24.65 & 26.00 & 0.00 & 40.00 & 9.90 & 310 \\
\cline { 2 - 9 } & Summer & 26.18 & 28.00 & 0.00 & 40.00 & 9.21 & 382 \\
\hline \multirow{2}{*}{ F3 } & Winter & 25.75 & 27.00 & 0.00 & 40.00 & 9.75 & 227 \\
\cline { 2 - 8 } & Summer & 25.73 & 27.00 & 0.00 & 40.00 & 9.62 & 179 \\
\hline \multirow{2}{*}{ F4 } & Winter & 21.84 & 22.00 & 0.00 & 40.00 & 10.56 & 534 \\
\cline { 2 - 8 } & Summer & 20.98 & 22.00 & 0.00 & 40.00 & 9.97 & 89 \\
\hline \multirow{2}{*}{ F5 } & Winter & 14.67 & 17.00 & 5.00 & 22.00 & 8.74 & 3 \\
\cline { 2 - 8 } & Summer & 29.50 & 28.00 & 22.00 & 40.00 & 8.58 & 4 \\
\hline
\end{tabular}

Table 8: Descriptive statistics for each treatment

\begin{tabular}{|l|r|r|c|}
\hline & \multicolumn{1}{|c|}{ Df } & F-value & P-value \\
\hline Treatments & 9 & 1.9749 & 0.038 \\
\hline & 2246 & & \\
\hline
\end{tabular}

Table 9: Brown-Forsythe test for the homogeneity of variances

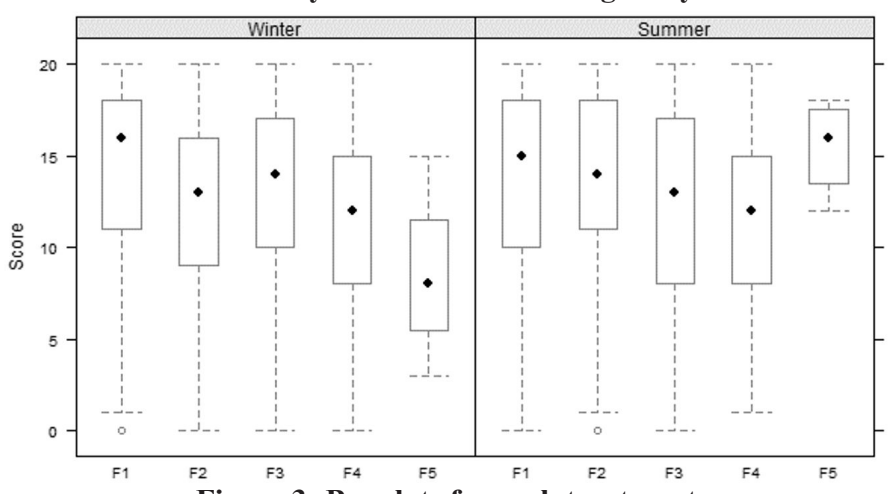

Figure 3: Boxplots for each treatment

\begin{tabular}{|l|r|r|r|r|r|}
\hline $\begin{array}{l}\text { Source of } \\
\text { variation }\end{array}$ & Df & $\begin{array}{c}\text { Sum of } \\
\text { squares }\end{array}$ & $\begin{array}{c}\text { Mean } \\
\text { square }\end{array}$ & F-value & P-value \\
\hline Intercept & 1 & 3327.4 & 3327.4 & 2274.259 & 0.000 \\
\hline Faculty & 4 & 36.0 & 9.0 & 6.155 & 0.000 \\
\hline Semester & 1 & 4.7 & 4.7 & 3.184 & 0.074 \\
\hline Faculty*Semester & 4 & 20.0 & 5.0 & 3.416 & 0.009 \\
\hline Errors & 2246 & 3286.0 & 1.5 & & \\
\hline
\end{tabular}

Table 10: ANOVA table (Type III sum of squares) 


\section{Discussion}

As the interaction effect in the analyses turned out to be significant, the main effects of faculty and semester were also retained in the models. One may conclude that there is difference among scores obtained by students of different faculties and these differences are not the same in each semester. Due to low p-values for faculty and interaction between faculty and semester, we may conclude that faculty is a factor that determines the score obtained from mathematics course.

Table 11 presents treatment means for sum of scores from both tests, mid-term test and final test. It can be observed that students from the Faculty of Finance and Accounting (F1) tend to obtain the highest scores each semester. However, students of this faculty tend to score slightly less in the second semester than in the first semester. These phenomena can also be observed for the mid-term and final tests. Students of the Faculty of International Relations (F2) tend score almost equally well as the students of Faculty of Finance and Accounting in the second semester. On the other hand, students of this faculty have much lower scores in the first semester. Students of the Faculty of Business Administration (F3) perform equally well in both semesters in both tests and students of Faculty of Informatics and Statistics (F4) obtain the lowest scores in both semesters. As mentioned above, students of Faculty of Economics do not take the course as compulsory one and it is hard to predict the reason why a particular student of this faculty takes the course.

We have to note that the differences between the scores obtained by students of different faculties may be caused by the fact that for enrolling to some programs, mainly at Faculty of Finance and Accounting and Faculty of Informatics and Statistics, students should exhibit some interest in mathematics prior to beginning of their bachelor studies as discussed in the previous paper (Otavová and Sýkorová, 2015). For this reason it would be interesting to include the score from entrance examinations into as independent variable into our model. Some authors have already analysed the relationship between entrance examinations and study performance. Klůfa (2015) shows that student's performance, i.e. score in mathematics in this case, is associated with the way how student was accepted to the university. Kučera, Svatošová, and Pelikán (2015) also conclude that student's performance can to some extend be predicted from results of entrance examinations.

\begin{tabular}{|c|c|c|c|c|c|c|c|}
\hline & \multirow{2}{*}{ Semester } & \multicolumn{5}{|c|}{ Faculty } & \multirow{2}{*}{ Overall } \\
\hline & & $\mathrm{F} 1$ & F2 & F3 & F4 & F5 & \\
\hline \multirow{3}{*}{$\begin{array}{l}\text { Both } \\
\text { tests }\end{array}$} & Winter & 42.39 & 36.95 & 38.92 & 33.16 & 23.33 & 36.73 \\
\hline & Summer & 40.25 & 40.02 & 38.21 & 32.15 & 45.00 & 39.02 \\
\hline & Overall & 41.24 & 38.65 & 38.61 & 33.02 & 35.71 & 37.68 \\
\hline \multirow{3}{*}{$\begin{array}{l}\text { Mid- } \\
\text { term test }\end{array}$} & Winter & 14.52 & 12.26 & 13.17 & 11.32 & 8.67 & 12.45 \\
\hline & Summer & 13.78 & 13.85 & 12.49 & 11.17 & 15.50 & 13.32 \\
\hline & Overall & 14.13 & 13.14 & 12.87 & 11.30 & 12.57 & 12.81 \\
\hline \multirow{3}{*}{ Final test } & Winter & 27.87 & 24.65 & 25.75 & 21.84 & 14.67 & 24.28 \\
\hline & Summer & 26.47 & 26.18 & 25.73 & 20.98 & 29.50 & 25.70 \\
\hline & Overall & 27.11 & 25.51 & 25.74 & 21.72 & 23.14 & 24.87 \\
\hline
\end{tabular}

\section{Table 11: Treatment means}

Boháčková and Brožová (2012) concluded that there are differences between the scores obtained from students of different study programs. However, that study included students from one faculty. In this study students come different faculties. Similarly, Kaspř́ková (2012) discusses that students of different study programmes score differently and she also concludes that students of Finance and Business obtain highest scores, while students of Informatics score low. Since these study programmes are offered by different faculties, we can conclude that our results coincide with her findings, as Finance programmes is offered by F1, Business programmes by F3 and Informatics by F4.

Motivation is one of the possibilities to reduce the differences among students of different faculties. Pacáková (2013) shows that allowing students to pass the course based on the mid-term tests might motivate students to study more. In our setting, the amount of points for the mid-term test could be increased, or more tests throughout the semester could be done in order to increase students' motivation to study throughout the semester. Another possibility, discussed by Brožová and Rydval (2014) is to increase the number of hours dedicated for the course and they show that scores and grades are worse when the number of hours are lower. Kolari, Savander-Ranne, and Viskari (2008) discuss various reasons why students are not motivated to study and why they study less hours than required. They focus on reasons such as student's background and different learning strategies and suggest that teachers should give advice on outof-class learning strategies as well.

\section{Conclusion}

The scores of students were used to analyse the differences among different faculties. The differences observed for sum of the scores from mid-term test and final test remained when the scores from both tests were analysed separately. Hence, the students of different faculties perform differently in the mathematics course and these differences persist during the entire semester. As the faculty was shown to be a determinant of the score from mathematics in this study, a further discussion may be launched on what are the causes of these differences and the ways of reducing them.

In future research we would like to concentrate on long-term evolution of the scores, collect other information about the students, such as score from entrance examination, as covariates. Currently we are in process of collecting these data.

\section{Acknowledgements}

This paper was processed with contribution of long term institutional support of research activities by Faculty of Informatics and Statistics, University of Economics, Prague.

\section{References}

Boháčková, I. and Brožová, I. (2012) 'Assessing Students' Level of Knowledge in Profile Courses of Choosen Economic Study Programmes at the FEM CULS', Journal on Efficiency and Responsibility in Education and Science, Vol. 5, No. 3, pp. 148-156.

Brožová H. and Rydval J. (2014) "Analysis of Exam Results of the Subject 'Applied Mathematics for IT'", Journal on Efficiency and Responsibility in Education and Science, Vol. 7, No. 3-4, pp. 59-65.

Clotfelter, C. T., Ladd, H. F., and Vigor, J. L. (2007) 'How and Why Do Teacher Credentials Matter for Student Achievement?' Working Paper, Cambridge, MA: National Bureau of Economic Research.

Hassanbeigi, A. et al (2011) 'The relationship between study skills and academic performance of university students', Procedia Social Behavioral Science, Vol. 30, pp. 1416-1424.

Kaspř́ková, N. (2011) 'Multivariate Analysis of Examination 
Papers', Proceedings of the 8th International Conference on Efficiency and Responsibility in Education (ERIE 2011), Prague, pp. 120-127.

Kaspříková, N. (2012) 'Data Analysis of Students' Performance', Proceedings of the 9th International Conference on Efficiency and Responsibility in Education (ERIE 2012), Prague, pp. 213218.

Kaspríková, N. (2013) 'Evaluation of the Test within the Latent Variable Models Framework', Proceedings of the 10th International Conference on Efficiency and Responsibility in Education (ERIE 2013), Prague, pp. 264-269.

Klůfa, J. (2012) 'Tests from Probability Point of View', Proceedings of the 9th International Conference on Efficiency and Responsibility in Education (ERIE 2012), Prague, pp. 229233.

Klůfa, J. (2013a) 'Comparison of Entrance Examinations in Mathematics', Proceedings of the 10th International Conference on Efficiency and Responsibility in Education (ERIE 2013), Prague, pp. 270-275.

Klůfa, J. (2013b) Učebnice matematiky pro studenty VŠE, Prague: Ekopress.

Klůfa, J. and Kaspř́iková, N. (2013) Mathematics for Economic Universities, Prague: Ekopress.

Klůfa J. (2015) 'Comparison of The Ways of Acceptance Students at University', Journal on Efficiency and Responsibility in Education and Science, Vol. 8, No. 3, pp. 72-76.

Kolari, S., Savander-Ranne, C. and Viskari E.L. (2008) 'Learning needs time and effort: a time-use study of engineering students', European Journal of Engineering Education, Vol. 33, No. 01, pp. 483-498.

Kučera, P., Svatošová, L., and Pelikán, M. (2015) 'University study results as related to the admission exam results', Proceedings of the 12th International Conference on Efficiency and Responsibility in Education (ERIE 2015), Prague, pp. 318 324.

Kutner, M.H., Nachtsheim, Ch.J., Neter, J., and Li.,W. (2005) Applied Linear Statistical Models, $5^{\text {th }}$ Edition, New York: McGraw-Hill Irwin.

Otavová, M. and Sýkorová, I. (2014) 'Analysis of Scores from Mid-Term and Final Test by a Contingency Table', Proceedings of the 11th International Conference on Efficiency and Responsibility in Education (ERIE 2014), Prague, pp. 527-533. Otavová, M. and Sýkorová, I. (2015) 'Analysis of Differences in the Scores of Students From Different Faculties', Proceedings of the 12th International Conference on Efficiency and Responsibility in Education (ERIE 2015), Prague, pp. 422-429.

Pacáková, Z. (2013) 'Motivation to Study - Students' Motivational Response on Various Motivational Actions in Statistical Courses', Journal on Efficiency and Responsibility in Education and Science, Vol. 6, No. 4, pp. 294-307.

Sahai, H. and Ageel, M.I. (2000) The Analysis of Variance: Fixed, Random and Mixed Models, Boston: Birkhäuser.

Sengodan, V. and Iksan, Z. H. (2012) 'Students' learning styles and intrinsic motivation in learning mathematics.' Asian Social Science, Vol. 8, No. 16, pp. 17-23.

Venables, W. N. and Ripley, B. D. (2002) Modern Applied Statistics with $S$, 4th Edition, New York: Springer. 